\section{The Use of Soil Amendments to Improve Survival of Roadside Grasses}

\author{
Rebecca Nelson Brown ${ }^{1}$ \\ Department of Plant Sciences and Entomology, University of Rhode Island, \\ 210 Woodward Hall, Kingston, RI 02881
}

\author{
Josef H. Gorres \\ Department of Plant and Soil Science, 258 Jeffords Hall, University of Vermont, \\ Burlington, VT 05405
}

Additional index words. biosolids, composted yard waste, Lolium perenne, Festuca rubra, Festuca arundinacea, Puccinellia distans, Agrostis idahoensis, Poa pratensis, Deschampsia cespitosa

\begin{abstract}
Highway rights-of-way are routinely planted with turfgrasses to prevent erosion, filter runoff, and improve aesthetics. However, the roadside is a harsh environment, and perennial grasses often die within the first year, leading to bare ground and annual weeds, which do not prevent erosion during the winter. To improve the survival of perennial vegetation on the roadside, it is necessary to identify the factors limiting vegetation growth and then to either identify plants that can tolerate those factors or identify ways to ameliorate the stresses while still maintaining safety. This study was designed to evaluate the effects of improved cultivars, salt tolerance, and organic matter amendments on perennial grass survival along two highways in Rhode Island. The amendments tested were processed biosolids and composted yard waste, each applied in a 50:50 mixture by volume with existing roadside soil; plain soil was included as a control. We tested 20 improved turfgrass cultivars and one seed mixture with common creeping red fescue (Festuca rubra L.) as the standard. Turfgrass species tested were perennial ryegrass (Lolium perenne $\mathbf{L}$.), tall fescue (Festuca arundinacea Schreb.), red fescue, alkali grass [Puccinellia distans (Jacq.) Parl.], idaho bentgrass (Agrostis idahoensis Nash), tufted hairgrass [Deschampsia cespitosa (L.) P. Beauv.], and kentucky bluegrass (Poa pratensis L.). We found that soil amendment was more effective than either improved genetics or salt tolerance. Establishment, vertical growth, and persistence of vegetation cover were significantly improved by amendment with organic matter, particularly biosolids. In Summer 2009 (the second growing season), turf cover exceeded $50 \%$ in the biosolids plots but was below $20 \%$ in the plain soil plots with complete loss of cover in the plain soil plots at one location. Kentucky bluegrass, tall fescue, red fescue, and idaho bentgrass showed the best persistence at the species level, and there were no consistent differences among cultivars.
\end{abstract}

Since the development of the first parkways in the early 20 th century, mowed turfgrasses have been preferred vegetation for use on the shoulders and medians of limited access roadways in the United States (FHWA, 2003). In addition to their aesthetic qualities, these grasses prevent soil erosion, trap dust, and filter storm water while not posing a hazard to errant vehicles. However, the roadside is a hostile environment, and turfgrasses struggle to survive, particularly within $5 \mathrm{~m}$ of the pavement. The soil remaining in the highway right-of-way after construction is generally of poor quality, low in organic matter and

Received for publication 22 Mar. 2011. Accepted for publication 1 Aug. 2011.

This research was funded by grant number RIDOT-RTD-07-2A from the Rhode Island Department of Transportation.

We thank Shelene Clark of the RIDOT Maintenance Division for coordinating our use of RIDOT equipment and crews and for obtaining the soil amendments. Carl Sawyer provided invaluable assistance with establishing the trials.

${ }^{1}$ To whom reprint requests should be addressed; e-mail brownreb@uri.edu. abundance increased with the level of nitrogen deposition. This is also the area of highest salt deposition (Bryson and Barker, 2002; Hutchinson and Olson, 1967; Prior and Berthouex, 1967). Spencer et al. (1988) found interactions between salinity and nitrogen uptake in perennial ryegrass (Lolium perenne) suggesting that sodium chloride enhanced plant uptake of $\mathrm{NO}_{\mathrm{x}}$. Bowman et al. (2006) found interactions in tall fescue (Festuca arundinacea Schreb.) showing that damage from sodium chloride was less severe when nitrogen levels were low than when plants were nitrogen-replete. However, both experiments used nitrogen levels sufficient to prevent stunting and chlorosis of the ryegrass, so the results may not apply to roadsides with infertile soil.

To improve the survival of perennial vegetation on the roadside, it is necessary to identify the specific factors limiting vegetation growth and then to either identify plants that can tolerate those factors or identify ways to ameliorate the stresses while still maintaining safety. This study was designed to evaluate the effects of improved cultivars, salt tolerance, and organic matter amendments on perennial grass survival along two highways in Rhode Island. It was initiated in response to widespread erosion and slope failure along limited access highways after two unusually snowy winters and extensive loss of perennial turf cover.

There has been a limited amount of published work on improving the survival of roadside grasses. In the 1960s and 1970s, researchers at the University of Rhode Island determined that low soil fertility and poor mowing practices were the major limiting factors for establishment and survival of roadside grasses (Wakefield et al., 1974, 1981). They recommended the use of red fescue (Festuca rubra L.), sheeps fescue (Festuca ovina L.), and 'Exeter' colonial bentgrass (Agrostis capillaris L.), all of which tolerate acidic, infertile soil, and seasonal drought. They also recommended the use of topsoil, annual fertilization, and a mowing height of $10 \mathrm{~cm}$. Red fescue is still a major component of roadside seed mixes in Rhode Island and throughout New England (RIDOT, 2004) but fertilization was discontinued as being too labor-intensive and the use of wide flail mowers (2 to $3 \mathrm{~m}$ ) on uneven ground inevitably resulted in scalping of vegetation and soil. At the same time, increased traffic levels and changes in deicing practices increased the salt deposition levels on roadsides.

Biesboer et al. (1998) evaluated the survival of 14 native and introduced grasses within $5 \mathrm{~m}$ of the pavement along urban roadsides in Minnesota. They concluded that high salt levels were responsible for poor establishment and survival of seedlings and that low nitrogen levels and poor soil structure reduced persistence of those species that successfully established. Only the highly salt-tolerant alkaligrass [Puccinellia distans (Jacq.) Parl.] was able to survive within $1 \mathrm{~m}$ of the pavement in their trials, and persistence of alkaligrass was attributed to the species' heavy seed production even when mowed. Numerous 
studies have evaluated the salt tolerance of standard turfgrass species (reviewed in Marcum, 2009), and breeders are actively working to improve salt tolerance. However, most studies have been conducted under conditions of non-limiting moisture and fertility, which rarely occur on roadsides; often studies are conducted in the greenhouse. A number of researchers have evaluated grasses for use in low-input lawns with extremely limited moisture and low fertility (Dernoeden et al., 1998; Diesburg et al., 1997; McKernan et al., 2001; Mintenko et al., 2002). However, these studies have not exposed the grasses to the salt and other pollutants common on roadsides. Research in Texas, Connecticut, and Washington, DC, has shown that addition of composted organic matter to roadside soils improves establishment and persistence of perennial grasses by increasing soil fertility and water retention (Block, 2000; EPA, 1997). However, the incorporation of compost had no effect on perennial grass establishment in Iowa and Florida (Harrell, 2002; Richard et al., 2002). In Florida, the limiting factor for vegetation establishment was rainfall, whereas in Iowa, vegetation established effectively in unamended soil.

This study had two objectives. The first was to determine whether improved turfgrass cultivars selected for tolerance to either low-input or saline conditions were superior to common creeping red fescue under roadside conditions. Newer improved cultivars are generally not used on roadsides because seed is more expensive than for common types or old cultivars. The second objective was to determine whether amendment of existing roadside soil with organic matter would improve long-term persistence of perennial grasses. Incorporation of organic matter at planting is more feasible than yearly fertilization for highway departments, but there was concern that the increased organic matter would result in soil salinization and turf damage.

\section{Materials and Methods}

Plant materials. Twenty-two turfgrass entries were included in this study. Twenty improved cultivars and one seed mixture were selected by industry breeders (Table 1 ); these cultivars had been developed for salt tolerance, adaptation to low-input environments, or both. The cultivars represented seven species: red fescue, alkaligrass, kentucky bluegrass (Poa pratensis L.), tufted hairgrass [Deschampsia cespitosa (L.) P. Beauv.], perennial ryegrass (Lolium perenne L.), idaho bentgrass (Agrostis idahoensis Nash), and tall fescue. Common creeping red fescue was included as a standard cultivar because it is the primary component of the seed mixes currently used by RIDOT (RIDOT, 2004).

Soil treatments. The three soil treatments were unamended soil, soil amended with $50 \%$ biosolids by volume, and soil amended with $50 \%$ composted yard waste by volume. The composted yard waste was obtained from Rhode Island Resource Reclamation; it consisted primarily of ground wood and leaves and had not been screened. The biosolids were obtained from the West Warwick Sewage Treatment Plant. They had been processed but not composted and resembled very fine black sand. Selected properties were collated from data given by the suppliers of the amendments (Geremia Associates, 2010; Rhode Island Resource Reclamation, personal communication) and are shown in Table 2.

Locations. The study was conducted in two locations. One site was on the shoulder of interstate 95 northbound between exits 2 and 3 in Hopkinton, RI (I-95). The highway at this site runs from southwest to northeast.

The second site was in the divider strip between interstate 295 northbound and a state police weigh station just north of exit 9 in Lincoln, RI (I-295). The highway at this site actually runs from west to east. The two locations were chosen to represent the extremes in snowfall for mainland Rhode Island. The I-95 site is in southwestern Rhode Island and is under coastal influence, receiving more rain and less snow than the I-295 site, which is inland in north-central Rhode Island.

Field plot design and establishment. We used a split-plot design with the soil treatments as the main plots and the turfgrass cultivars as the subplots (Ruxton and Colgrave, 2003; Steel and Torrie, 1980). Each individual subplot was $1.2 \mathrm{~m} \times 1.8 \mathrm{~m}$ with the long dimension running perpendicular to the roadway. Each main plot was $80.5 \mathrm{~m}$ long $\times 1.8 \mathrm{~m}$ wide with the long dimension running parallel to the roadway. Main plots were separated by a 4-m buffer zone to prevent mixing of amendments. Although the main plots were not replicated in space at each site, each main plot was divided into three sections and the entire set of turfgrass cultivars was planted in randomized order within each section. The experimental unit for all data collection was the individual subplot. This pseudoreplication of the main plots facilitated incorporation of the soil amendments; the relatively small area occupied by the entire study at each location made it unlikely that location within the study area would have a significant effect distinct from the treatment effect.

The trials were established in Sept. 2007 with I-95 seeded on 22 Sept. and I-295 on 24 Sept. Existing vegetation consisted primarily

Table 1. Turfgrass cultivars used in roadside trials. ${ }^{2}$

\begin{tabular}{|c|c|c|c|c|}
\hline Variety & Species & Scientific name & $\begin{array}{c}\text { Seeding rate } \\
\left(\mathrm{kg} \cdot \mathrm{ha}^{-1}\right)\end{array}$ & Seeds $/ \mathrm{kg}$ \\
\hline Pure Gold & Tall fescue & Festuca arundinacea Schreb. & 255 & $80,100-105,300$ \\
\hline Epic & Red fescue & Festuca rubra L. & 157 & 164,250 \\
\hline Tarheel II & Tall fescue & Festuca arundinacea Schreb. & 255 & $80,100-105,300$ \\
\hline GolfStar & Bentgrass & Agrostis idahoensis Nash & 37 & $2,700,000$ \\
\hline Salinas & Perennial ryegrass & Lolium perenne L. & 190 & $94,500-121,500$ \\
\hline IS-TF154 & Tall fescue & Festuca arundinacea Schreb. & 255 & $80,100-105,300$ \\
\hline SeaLink & Red fescue & Festuca rubra L. & 130 & 164,250 \\
\hline Fiesta 3 & Perennial ryegrass & Lolium perenne L. & 190 & $94,500-121,500$ \\
\hline Common creeping & Red fescue & Festuca rubra L. & 157 & 164,250 \\
\hline Pro-OC-1 & Tufted hairgrass & Deschampsia cespitosa (L.) P. Beauv. & 130 & 585,000 \\
\hline 7.0013 & Alkaligrass & Puccinellia distans (Jacq.) Parl. & 37 & 900,000 \\
\hline 7.0855 & Alkaligrass & Puccinellia distans (Jacq.) Parl. & 37 & 900,000 \\
\hline \multirow[t]{5}{*}{ Experimental DOT mix } & $20 \% \mathrm{~J}-5$ Chewings fescue & Festuca rubra L. ssp. fallax (Thuill.) Nyman & 255 & \\
\hline & $20 \%$ Fults alkaligrass & Puccinellia distans (Jacq.) Parl. & & \\
\hline & $10 \%$ GolfStar idaho bentgrass & Agrostis idahoensis Nash & & \\
\hline & $20 \%$ Top Gun II perennial ryegrass & Lolium perenne L. & & \\
\hline & $30 \%$ Bluechip kentucky bluegrass & Poa pratensis L. & & \\
\hline
\end{tabular}

${ }^{\mathrm{z}}$ All seed samples were supplied by industry breeders and had comparable levels of pure live seed. Seeds per kilogram is based on published values, not on actual seed counts. 
of crabgrass. The entire trial area was rototilled to a depth of $5 \mathrm{~cm}$ with a tractor-mounted rototiller and all rocks larger than fist size were removed. For the compost and biosolids treatments, a $5-\mathrm{cm}$ thick layer of compost or biosolids was spread over the tilled soil and then incorporated to a depth of $10 \mathrm{~cm}$. The plain soil treatment was rototilled a second time to a depth of $10 \mathrm{~cm}$ but no amendments were incorporated. The area was not limed because the initial soil $\mathrm{pH}$ in the trial area was above 6.0. The beds were raked smooth and subplots marked with string. Turfgrass cultivars were seeded by hand at half the recommended lawn seeding rate for each species (Brede, 2000; Christians, 2004). Seed was obtained directly from the seed company or breeder and met Oregon certification standards for purity and germination (OSCS, 2011). Certification standards for turfgrass seed generally specify pure seed in excess of $90 \%$ and germination rates exceeding $80 \%$. Each plot was lightly raked to incorporate the seed. The entire trial was then hydromulched following RIDOT guidelines (RIDOT, 2004) except that no seed was included in the mixture. The hydromulch mixture included a water-soluble fertilizer, which provided nitrogen, phosphate, and potash at a rate of $93.5 \mathrm{~kg} \cdot \mathrm{ha}^{-1}$ per RIDOT specifications. Each location received a single application of 1.25 $\mathrm{cm}$ of water the second week of October to ensure that all entries established successfully. After establishment, the trial areas were maintained by RIDOT crews in a manner identical to the surrounding roadside. This maintenance consisted of occasional mowing with a tractormounted industrial flail mower; the nominal height of cut was $7.6 \mathrm{~cm}$ (RIDOT, 2004).

Soil testing. Soil samples were taken in Sept. 2010 to evaluate the long-term effects of soil amendments. Soil cores were collected with a standard soil core sampler every $1.5 \mathrm{~m}$ down the length of each main plot and then thoroughly blended to create the test samples for each plot. Soil texture, organic matter content, and concentration of all nutrients other than nitrogen were determined by the University of Connecticut Soil Nutrient Analysis Laboratory using standard procedures. Plant-available nitrogen was estimated from the $\mathrm{CO}_{2}$ burst measured using the Solvita Haney-Brinton test system (Woods End Laboratories, Mount Vernon, ME). Carbon dioxide release and soil nitrogen content are strongly correlated with nitrogen in pounds per acre equal to $50 \%$ of the amount of $\mathrm{CO}_{2}$ (in ppm) released in $24 \mathrm{~h}$ (Haney et al., 2008).

Data collection and analysis. Percent living turf cover was estimated visually for each plot in spring, summer, and fall of each year beginning with Fall 2007 and ending with Summer 2009. Turf height was measured in Apr. 2008, before the first mowing. Measurements were made to the nearest centimeter using a standard ruler to measure the distance from the soil to the canopy top at four locations in each plot. Dormancy was visually rated on a 1 to 9 scale (1 indicates fully dormant) in late July 2008 after a 6-week drought. Data were analyzed using repeated- measures analysis of variance (ANOVA) for the percent cover data and standard GLM ANOVA for other data. Fisher's least significant difference test was used for means separations because it is robust to unequal replication. A significance threshold of $\alpha=0.05$ was used throughout.

\section{Results}

There were significant differences between locations, between soil amendment treatments within location, between species within soil amendment treatment, and between turfgrass cultivars.

Differences between locations. Repeatedmeasures ANOVA showed that the turf cover was significantly greater at I-95 than at I-295. The overall means for the two locations were $40 \%$ and $33 \%$, respectively. Turf cover was also greater at I-95 for all treatments on all dates with a few exceptions (Fig. 1). In Nov. 2008, cover was greater at I-295 for the biosolids and compost treatments because the I-295 site had not been mowed since July, whereas the I-95 site had been mowed regularly. Cover of the planted turfgrasses declined in the biosolids treatment at I-95 during the summer of 2009 as a result of invasion by quackgrass. As a result, turfgrass cover was lower than at I-295, although total vegetation cover was not. The differences between locations are likely the result of differences in soil moisture, because the soil is sandier at I-295 (Table 3) and the site is surrounded by pavement on all sides, whereas the I-95 site has a wooded back slope to the southeast. The area outside the plots at I-295 is dominated by annual grasses, chiefly crabgrass [Digitaria ischaemum (Schreb.) Schreb. ex Muhl.] and prairie three-awn (Aristida oligantha Michx.), whereas the vegetation is more varied at I-95 and includes an abundance of perennial grasses and forbs.

Differences between soil treatments. Data for the two locations were analyzed separately. However, the soil treatment effects followed the same pattern at each location (Fig. 1). Turf cover was lower in the plain soil plots than in the amended plots throughout the study. The overall cover averages for I-95 were $54 \%$ for the biosolids treatment, $39 \%$ for the compost treatment, and $26 \%$ for the plain soil treatment. At I-295, the averages were $58 \%, 33 \%$, and $9 \%$ for biosolids, compost, and soil, respectively. Differences were already apparent in Nov. 2007 and increased during the spring of 2008. By May, the turf in

Table 2. Organic matter, nitrogen, and phosphate averages (1 SD) as reported by suppliers for biosolids and compost amendments used in trials.

\begin{tabular}{lcccccc}
\hline & $\begin{array}{c}\mathrm{SOM}^{z} \\
\%\end{array}$ & $\mathrm{C}: \mathrm{N}^{\mathrm{y}}$ & $\begin{array}{c}\mathrm{NO}_{3}-\mathrm{N} \\
\left(\mathrm{mg} \cdot \mathrm{kg}^{-1}\right)\end{array}$ & $\begin{array}{c}\mathrm{NH}_{4}-\mathrm{N} \\
\left(\mathrm{mg} \cdot \mathrm{kg}^{-1}\right)\end{array}$ & $\begin{array}{c}\text { Total N } \\
\left(\mathrm{mg} \cdot \mathrm{kg}^{-1}\right)\end{array}$ & $\begin{array}{c}\mathrm{Total}_{\mathrm{PO}_{4}} \\
\left(\mathrm{mg}^{\mathrm{k}} \mathrm{kg}^{-1}\right)\end{array}$ \\
\hline Biosolids & $17(4.0)$ & 6.7 & $120(110)$ & $4225(1617)$ & $12516(3907)$ & $2185(2603)$ \\
Compost & $45(7.8)$ & 64 & $13.5(6.8)$ & $808(636)$ & $3507(2665)$ & $126(81)$ \\
\hline
\end{tabular}

${ }^{\mathrm{z}}$ As volatile solids from loss-on-ignition.

${ }^{\mathrm{y}}$ Derived from \% SOM and total $\mathrm{N}$.

$\mathrm{SOM}=$ soil organic matter; $\mathrm{C}: \mathrm{N}=$ carbon:nitrogen.

Turf Persistence at 1-95

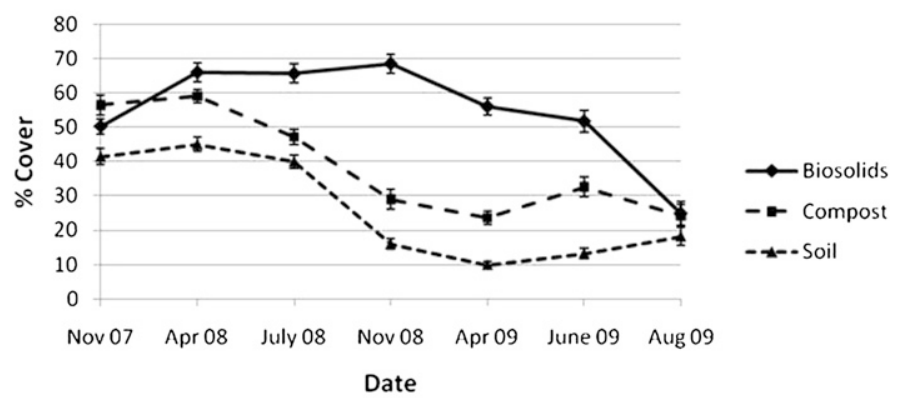

Turf Persistence at I-295

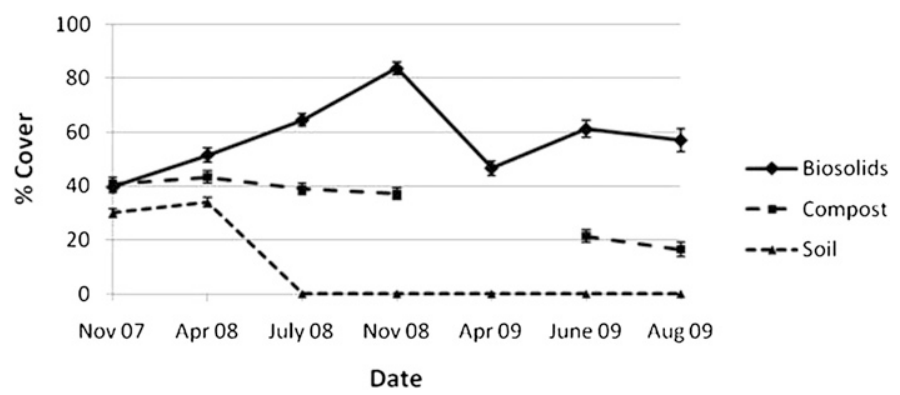

Fig. 1. Turfgrass persistence at I-95 and I-295, averaged across all turfgrass cultivars. Cover was estimated visually; values are the mean of three replications. Error bars indicate the SE for each mean. Data were not available for the compost treatment at I-295 in Apr. 2009. 
the biosolids plots was dark green and lush, whereas turf in the compost plots was noticeably nutrient-deficient and turf in the plain soil plots was severely stunted and chlorotic. The grass was also significantly taller in the biosolids plots than in the compost or plain soil plots for all species except idaho bentgrass and tufted hairgrass, for which there were no height differences (Fig. 2).

Six weeks without rain in June and July 2008 resulted in the turf at both locations becoming drought-stressed and going dormant or dying. Dormancy was most extensive in the plain soil treatment at both locations. In the plain soil treatment at I-295, all turfgrass plots were completely killed, whereas at I-95, individual turfgrass entry scores ranged from 1.3 to 3.7 on a 1 to 9 scale where 1 is completely dormant. Turfgrass plots in the biosolids treatment went dormant but were not killed. At I-95, the biosolids treatment was significantly superior to either the compost treatment or the plain soil treatment, whereas at I-295, the compost treatment was slightly better than the biosolids treatment, although they did not differ statistically.

Much of the turf recovered from dormancy in the biosolids treatment at both locations, and turf cover increased over the fall of 2008 . Recovery was not observed in the compost or plain soil treatments at either location; cover remained constant or declined between July and November (Fig. 1). Cover decreased over the winter of 2008-2009 with the sharpest decrease in the biosolids treatment plots, which had the most cover going into the winter. Between Apr. and Aug. 2009, the average turfgrass cover decreased sharply in the biosolids treatment at I-95 but increased slightly at I-295. Decrease in cover was primarily the result of weed invasion, particularly of quackgrass. Cover increased in the compost and plain soil treatments, although it remained significantly lower than in the biosolids treatment. At I-295, cover in the plain soil treatment remained constant at $0 \%$. Data were not available for the compost treatment at I-295 in Apr. 2009, but levels in June and August were lower than for Nov. 2008. The biosolids-amended soil plots supported significantly greater cover of perennial vegetation than either of the other treatments from May 2008 through Aug. 2009 and beyond, although an increasing percentage of that vegetation was naturally occurring species rather than the grass species deliberately seeded into the plots. This was particularly true at I-95, where there was a greater amount of perennial vegetation in the area around the trial plots.

The soil in the trial areas was sampled in Sept. 2010, just over 1 year past the conclusion of the study. The soil at I-295 is sandier than at I-95; available water capacities calculated with the Soil Water Characteristics Calculator (Saxton, 2009) were between 5\% and 7\% for I-95 and between 4\% and 6\% for I-295 (Table $3)$. Otherwise, the soils are similar. The plain soil plots at both locations contained belowoptimum levels of macronutrients, including phosphorous, and had very low microbial activity and plant-available nitrogen (Table 4).

Table 3. Soil physical properties 3 years after incorporation of amendments. ${ }^{z}$

\begin{tabular}{|c|c|c|c|c|c|c|c|}
\hline \multirow[b]{2}{*}{ Plot } & \multicolumn{3}{|c|}{ Texture $(\%)$} & \multirow{2}{*}{$\begin{array}{l}\text { Percent } \\
\text { SOM }\end{array}$} & \multirow[b]{2}{*}{$\mathrm{pH}$} & \multirow{2}{*}{$\begin{array}{l}\text { Available } \mathrm{H}_{2} \mathrm{O} \\
\text { capacity }(\%)\end{array}$} & \multirow{2}{*}{$\begin{array}{c}\text { Saturated hydraulic } \\
\text { conductance }\left(\mathrm{mm} \cdot \mathrm{h}^{-1}\right)\end{array}$} \\
\hline & Sand & Silt & Clay & & & & \\
\hline I-95 biosolids & 74.2 & 21.8 & 4.0 & 3.2 & 7.2 & 7.2 & 72.0 \\
\hline I-95 compost & 78.8 & 20.4 & 1.4 & 5.0 & 6.6 & 7.3 & 82.0 \\
\hline I-95 soil & 79.2 & 17.4 & 3.4 & 2.1 & 6.5 & 5.3 & 87.0 \\
\hline I-295 biosolids & 82.6 & 15.0 & 2.4 & 3.3 & 7.4 & 5.1 & 101.0 \\
\hline I-295 compost & 86.6 & 12.0 & 1.4 & 5.0 & 6.9 & 6.0 & 86.0 \\
\hline I-295 soil & 84.6 & 14.0 & 1.4 & 3.0 & 6.5 & 4.7 & 91.0 \\
\hline
\end{tabular}

${ }^{2}$ Soil texture was determined using a hydrometer method. Percent organic matter was determined using loss on ignition. Soil hydraulic parameters were computed from SOM and texture with the Soil Water Characteristics Calculator.

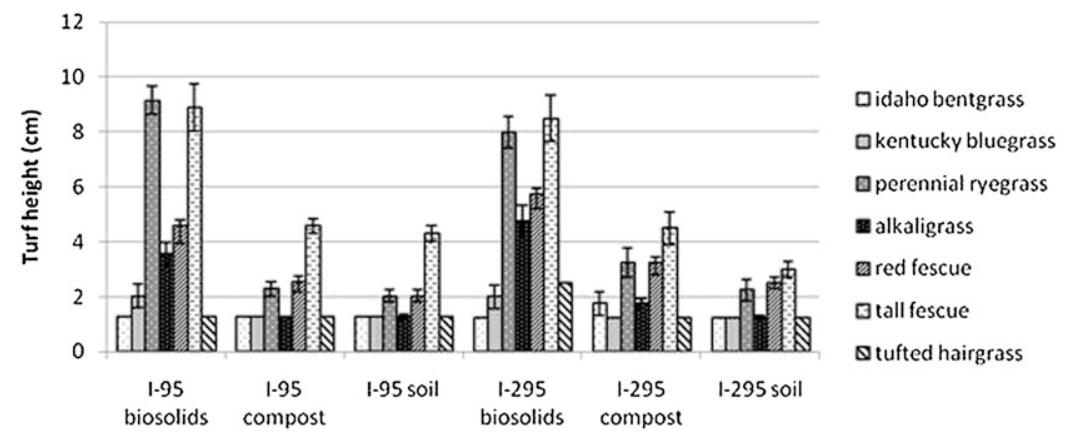

Fig. 2. Effect of soil amendments on vertical growth by species. Turf height in the biosolids treatments was significantly greater than in the other treatments for all species except idaho bentgrass and tufted hairgrass. Height was measured to the nearest centimeter using a standard ruler at four locations in each plot. Measurements were taken in May 2008 before the first mowing; values were averaged across all cultivars for each species. Error bars show SE of the mean; columns with no bars have a SE of 0 .

Table 4. Soil nutrient test results. ${ }^{\mathrm{z}}$

\begin{tabular}{|c|c|c|c|c|c|c|c|c|c|}
\hline \multirow[b]{2}{*}{ Plot } & \multicolumn{5}{|c|}{ Macronutrients $\left(\mathrm{kg} \cdot \mathrm{ha}^{-1}\right)$} & \multicolumn{4}{|c|}{ Metals (ppm) } \\
\hline & Nitrogen $^{y}$ & Phosphorus & Potassium & Calcium & Magnesium & Lead $^{x}$ & Copper & Zinc & $\overline{\text { Iron }}$ \\
\hline I-95 biosolids & 24.4 & $>112$ & 384 & $>4000$ & 223 & bg & 1.9 & 77.4 & $\overline{4.4}$ \\
\hline I-95 compost & 18.7 & 11 & 293 & 2287 & 160 & 212 & 2.1 & 97.7 & 14.0 \\
\hline I-95 soil & 15.6 & 9 & 148 & 855 & 93 & 295 & 7.9 & 130.8 & 12.5 \\
\hline I-295 biosolids & 24.3 & $>112$ & 355 & $>4000$ & 224 & bg & 1.6 & 44.7 & 4.5 \\
\hline I-295 compost & 16.5 & 22 & 311 & 1719 & 113 & 129 & 1.1 & 57.4 & 9.0 \\
\hline I-295 soil & 15.6 & 16 & 176 & 766 & 88 & 178 & 3.3 & 53.3 & 38.0 \\
\hline
\end{tabular}

${ }^{\mathrm{z}}$ All samples were taken 3 years after incorporation of amendments. All nutrients other than nitrogen were measured by the University of Connecticut Soil Analysis Laboratory using standard methods.

${ }^{y}$ Nitrogen was determined from $\mathrm{CO}_{2}$ respiration using the Solvita Haney-Brinton test.

${ }^{\mathrm{x}} \mathrm{bg}=$ typical background levels for agricultural soils.

Addition of composted yard waste significantly raised the soil organic matter (SOM) levels in both locations, as would be expected (Tables 2 and 3). The compost also increased the macronutrient levels; in some cases, this was sufficient to bring them into the optimal zone for plant growth (Table 4). Microbial activity (measured by $\mathrm{CO}_{2}$ respiration test) increased but not significantly. Biosolids did not raise SOM because it provided less soil organic matter than composted yard waste (Tables 2 and 3). Addition of biosolids increased the soil $\mathrm{pH}$ and levels of all macronutrients, which in some cases exceeded the optimum levels (Table 4). Microbial activity and plant-available nitrogen also increased significantly, although they were still below the level recommended for agricultural soils.

One concern with using biosolids as a soil amendment is that they have the potential to increase levels of heavy metals, particularly lead. Roadside soils frequently contain elevated levels of lead and other heavy metals; the plain soil treatments in this study had levels of 178 and 295 ppm at I-295 and I-95, respectively (Table 4). Interestingly, the lead content of soil from the biosolids plots was below background for both locations.

Performance of individual turfgrass species. For roadside grasses, the two most important components of performance are establishment and persistence. Thus, we focused on the percent cover data from Nov. 2007 (establishment) and June 2009 (persistence). We used the data from June rather than August for 2009 because the August data from the I-95 biosolids treatment were compromised by quackgrass intrusion into the plots. There were significant differences between species for both locations and all treatments in Nov. 2007 and for all treatment $\times$ location combinations except the plain soil treatment at I-295 for June 2009. There were no differences in that treatment because all the turfgrasses had died. Kentucky bluegrass, idaho bentgrass, and tufted hairgrass were each represented 
by only one cultivar. For idaho bentgrass and tufted hairgrass, this is a reflection of the paucity of commercial cultivars in these species. Only one cultivar of kentucky bluegrass was included because this species generally shows poor performance under low fertility, drought, or salinity; only one seed company was interested in including material in the trial. Thus, the performance of 'Diva' cannot be extrapolated to represent the performance of kentucky bluegrass as a species.

Perennial ryegrass and the experimental Department of Transportation (DOT) mix showed the best establishment in all treatments at both locations (Fig. 3). Tufted hairgrass was similar to these species in the biosolids treatment at I-95, whereas 'Diva' kentucky bluegrass, red fescue, and tall fescue were similar at I-295. Tall fescue was also similar in the compost treatment at I-295. Alkaligrass had very poor establishment in the compost treatment at both locations. In the plain soil treatment, both alkaligrass and idaho bentgrass had unacceptable establishment.

'Diva' kentucky bluegrass showed the best persistence in the biosolids treatment at I-295, with 90\% cover, in June 2009 (Fig. 4). Red fescue, idaho bentgrass, and tall fescue were similar, with $72 \%, 67 \%$, and $68 \%$ cover, respectively. Tall fescue showed the best persistence at I-95 with $75 \%$ cover. 'Diva' kentucky bluegrass, red fescue, and the experimental DOT mix were similar, with $60 \%, 59 \%$, and $55 \%$ cover, respectively. Tufted hairgrass showed poor persistence at both locations, whereas idaho bentgrass had very poor persis-

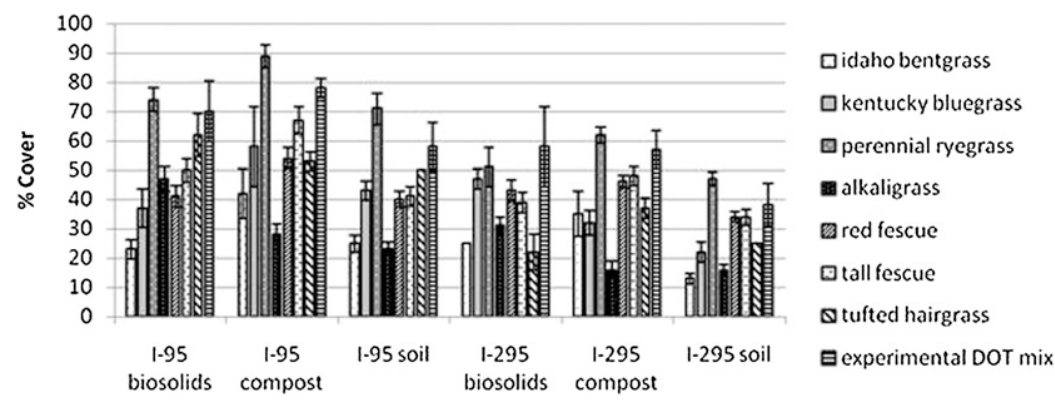

Fig. 3. Establishment was evaluated as percent cover (visual estimation) in Nov. 2007, 6 weeks after seeding. Data were pooled across all cultivars of each species. Compost gave the best establishment, although the differences were significant only in comparison with the unamended soil.

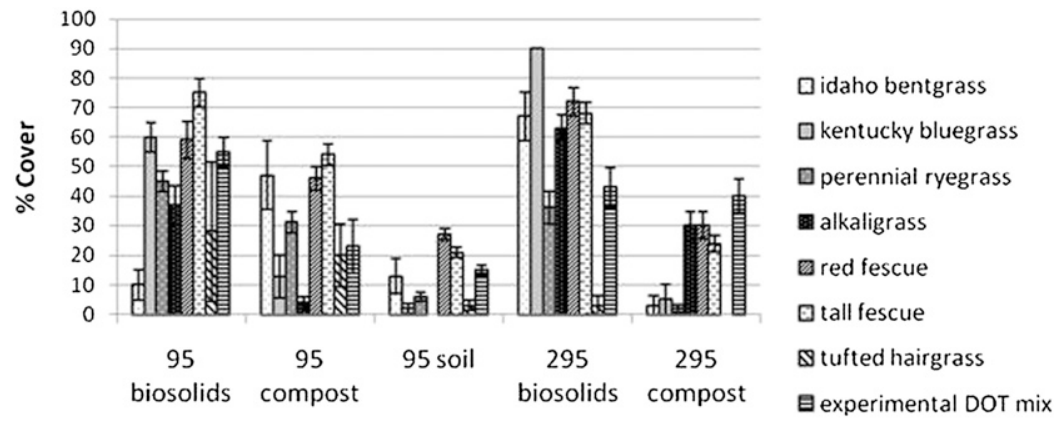

Location and Treatment

Fig. 4. Effect of location, soil amendment, and species on turfgrass persistence measured as percent cover by visual estimation in June 2009, 21 months after seeding. Error bars show SE of the mean. treatment, because growth was not limited by nutrient deficiency. Idaho bentgrass had the least vertical growth in both locations, reaching a height of only $1.3 \mathrm{~cm}$ (Fig. 2). 'Diva' kentucky bluegrass and tufted hairgrass were similar in height at both locations, and alkaligrass was similar at I-95. Red fescue and alkaligrass were intermediate in height at both locations. Red fescue averaged $4.3 \mathrm{~cm}$ at I-95 and $5.8 \mathrm{~cm}$ at $\mathrm{I}-25$; at both locations, it was significantly taller than idaho bentgrass but significantly shorter than either tall fescue or perennial ryegrass.

Performance of individual turfgrass cultivars. In the biosolids treatment at I-95, common creeping red fescue had the best cover in both June and Aug. 2009 with values of $82 \%$ and $75 \%$, respectively. In June 2009 , there were 10 other cultivars that were statistically similar; by August, that number had decreased to six. Cultivars that were similar on both dates were the red fescues 'Epic' and 'Cindy Lou', the tall fescues 'Blade Runner' and IS-TF154, 'Diva' kentucky bluegrass, and the experimental DOT mixture. At I-295, 'Diva' kentucky bluegrass had the best cover in both June and Aug. 2009 with values of $90 \%$ and $97 \%$, respectively. In June, there were 10 other cultivars that were similar; in August, there were ' 1 . However, there were only six cultivars that were similar to 'Diva' on both dates: the red fescues 'Cindy Lou', 'Epic', and 7.0929; the tall fescues IS-TF154 and 'Tarheel II', and the experimental alkaligrass 7.0855. When cover was compared over the entire study, the common creeping red fescue and the experimental DOT mixture were the best performers at I-95, whereas 'Diva' and 'Epic' were the best performers at I-295.

In the compost treatment at I-95, the top performer in June 2009 was the tall fescue 'Tarheel II' with 65\% cover. In August, the top performer was another tall fescue, IS-TF154, with $72 \%$ cover. Five cultivars were in the top group on both dates: 'Tarheel II', IS-TF154, 'Bingo', and 'Bladerunner' tall fescues and 'Cindy Lou' red fescue. At I-295, the top performer in the compost treatment in both June and August was the experimental alkaligrass 7.0013 with $50 \%$ cover. Five cultivars were similar in both months: the alkaligrass 'Fults', the red fescues 7.0929 and 'Sealink', the tall fescue 'Tarheel II', and the experimental DOT mixture. When cover was compared over the entire study, the tall fescue 'Bingo' was the top performer at I-95 and the experimental DOT mixture was the top performer at I-295.

There were no differences among cultivars in the plain soil treatment at I-295. At I-95, common creeping red fescue had the best cover in June with $30 \%$, whereas tufted hairgrass had the best cover in August with $58 \%$ cover. However, the cover in the tufted hairgrass plot was all seedlings; common creeping red fescue had the best true persistence with $50 \%$ cover. The cultivars similar to common red fescue were all red fescues or tall fescues; 'Sealink', 'Cindy Lou', 7.0929, 'Tarheel II', and 'Bingo' were similar on both 
dates. For the study as a whole, common creeping red fescue gave the best cover at I-95.

Variation within species. This study included multiple cultivars of red fescue, tall fescue, perennial ryegrass, and alkaligrass, enabling us to look at variation in performance between cultivars of the same species. This is important because DOT guidelines rarely specify beyond the species level for planting stock, and contractors generally use old or unimproved cultivars because seed is less expensive. There were no significant within-species differences in persistence based on percent cover in June 2009. There were significant differences in establishment (based on percent cover in Nov. 2007) among cultivars for red fescue, tall fescue, and alkaligrass but not for perennial ryegrass. Among the red fescue entries, the common type had the best establishment with $52 \%$ cover. The improved cultivar, Cindy Lou, was similar. All of the tall fescue entries had similar establishment except for 'Pure Gold'; it was significantly slower than the others with only $28 \%$ cover. Among the alkaligrass entries, the cultivar Fults and the experimental entry 7.0013 had the best establishment with $35 \%$ cover. Significant differences in vertical growth were identified in red fescue and tall fescue. Among the tall fescues, 'Pure Gold' was significantly shorter than the other cultivars; it had an average height of $2.8 \mathrm{~cm}$, whereas all the other cultivars were between 5.8 and $6.6 \mathrm{~cm}$. Among the red fescue entries, height ranged from $2 \mathrm{~cm}$ for 7.0013 to $5.6 \mathrm{~cm}$ for the common type. The cultivar SeaLink was similar to 7.0013; the common type was significantly taller than all other entries.

\section{Discussion}

This study was conducted to evaluate three approaches to improving the persistence of perennial turfgrasses on roadsides in Rhode Island: soil amendment with organic matter, the use of improved turfgrass cultivars, and the use of alternate turfgrass species tolerant of drought, low fertility, and/or salinity. We found that one-time amendment of soil with organic matter significantly improved turfgrass cover for the entire 2-year study. Biosolids had a significantly greater effect than yard waste compost; the effect of the single incorporation of biosolids continued to persist after 3 years. Turfgrass persistence in the unamended soil was poor or non-existent for all cultivars and species, indicating that there is little advantage to using improved cultivars or alternate species. There were significant differences among species, particularly in the biosolids-amended soil, but the traditional species red fescue, kentucky bluegrass, and tall fescue were superior to the alternate species. There were also significant differences among cultivars but no clear superiority of the improved red fescue cultivars over the common type in persistence. The improved cultivars were significantly shorter than the common type, but all the red fescues were significantly shorter than tall fescue and pe- rennial ryegrass. The one slender creeping red fescue, 'SeaLink', was not significantly different from the three strong creeping red fescues ('Epic', 'Cindy Lou', and common).

This study was begun with the hypothesis that road salt exposure was the primary reason for the failure of perennial grasses to persist within $5 \mathrm{~m}$ of the pavement. Salt has been shown to be a major limiting factor in other regions (Biesboer et al., 1998) and the kentucky bluegrass and common red fescue that make up the bulk of the standard seed mix have only moderate salt tolerance (Marcum, 2009). We expected that adding organic matter to the soil would increase sodium levels during the growing season, reducing turfgrass survival. Addition of compost has been shown to increase salinity both directly and by increasing the cation exchange capacity of the soil (Hargreaves et al., 2008). We rejected our initial hypothesis because increasing soil fertility enabled all the tested cultivars, including common red fescue, to survive although salt levels in runoff and snow regularly exceeded concentrations, which caused significant loss of green tissue in greenhouse tests (Brown, 2008, 2010; Krishnan, 2010). At the same time, even the extremely salt-tolerant alkaligrass did not survive in the plain soil treatments. The turfgrass species used in this study varied from moderately salt sensitive (idaho bentgrass, kentucky bluegrass, and tufted hairgrass) to extremely tolerant (alkaligrass), yet none of the species showed acceptable persistence in the plain soil treatments, and idaho bentgrass and kentucky bluegrass outperformed alkaligrass in the biosolids treatment at I-295.

The soil test results for the unamended plots indicate that the roadside soil is deficient in all macronutrients as well as being quite sandy, resulting in both high saturated hydraulic conductivity values and low available water capacities. Organic matter levels were similar to agricultural soils in Rhode Island, and $\mathrm{pH}$ was within the recommended range for turfgrass. We hypothesize that the lack of nutrients limited turf growth, persistence, and the ability to recover from damage. This hypothesis was supported by the excellent persistence of most of the turfgrasses in the biosolids-amended soil and the significant improvement in the soil amended with composted yard waste. In our amendments, the carbon:nitrogen $(\mathrm{C}: \mathrm{N})$ ratio (Table 2 ) for biosolids was $\approx 7$ indicating that $\mathrm{N}$ is likely mineralized from the large amount of total $\mathrm{N}$ available in biosolids. In contrast, the C:N ratio of compost was 64 , which favors immobilization of $\mathrm{N}$. This is in agreement with findings by Cowley et al. (1999) who reported that $39 \%$ to $49 \%$ of the $\mathrm{N}$ available in biosolids was mineralized in the first year compared with only $10 \%$ for composted yard waste. The biosolids had four times as much total $\mathrm{N}$ and five times greater ammonia- $\mathrm{N}$ content than the compost as is expected from literature data (e.g., Cowley et al., 1999). Phosphate content of biosolids used in this study exceeded that of compost by a factor of 17. This is not unexpected. The total phosphorous content of biosolids ranges from $1 \%$ to $4 \%$ of total dry weight (Epstein et al., 1976), although much of the phosphorous may be bound to inorganic molecules or strongly sorbed to soil surfaces leaving it unavailable to plants (McCoy et al., 1986). The total phosphorous content of composted yard waste is much lower, less than $0.1 \%$ (Grebus et al., 1994). The addition of organic matter to the soil has been shown to improve cation exchange capacity, moisture retention, and plant growth (Grebus et al., 1994; Hargreaves et al., 2008). Based on estimates from texture and SOM content, there was no appreciable increase in available water capacity in any of our treatments. Cation exchange capacity of organic matter is strongly dependent on $\mathrm{pH}$, increasing by $\approx 30 \%$ per $\mathrm{pH}$ unit (Brady and Weil, 2008). Any increase in SOM and $\mathrm{pH}$ will thus increase the ability of soils to store nutrients when there are amendments. Although the organic matter added in compost is greater, the increases in stored pools of cations are likely greatest in biosolid-amended soils where increases in $\mathrm{pH}$ and SOM coincide with cation additions. This would explain the resilience of turfgrasses in the biosolid treatment. The results for the compost treatments further support the conclusion that it is nutrients, not salt, that limit growth and resilience. The species with the best persistence were tall fescue, red fescue, idaho bentgrass, and alkaligrass, all of which are tolerant of infertile soils. Further research is needed to determine whether a blend of biosolids and composted yard waste would be superior to either amendment alone and to determine the best rate at which to amend the soil. The $50 \%$ biosolids rate used in this study resulted in excessive vertical growth, particularly for tall fescue, perennial ryegrass, and quackgrass.

The use of biosolids as a nutrient source for roadside turfgrasses is not new; Wakefield et al. (1974) recommended annual fertilization with biosolids to the Rhode Island Department of Transportation in the 1970s. However, concerns about heavy metal contamination of soil and water have limited the use of biosolids as a fertilizer. Biosolids can have high levels of heavy metals and have been shown to increase metal concentrations in agricultural soils (Alloway and Jackson, 1991; Walter and Cuevas, 1999). However, these soils generally have very low initial levels of heavy metals. In contrast, many urban soils, particularly on roadsides, have dangerously high levels of lead and other heavy metals (Imperato et al., 2003; Turer et al., 2001). Furthermore, the fate of heavy metals from biosolid-amended soils depends on both the rate of biosolid application and the soil type (Yang et al., 2008). Heavy metals may be sorbed strongly to the organic matter in the biosolids (Yang et al., 2008). The addition of biosolids alone or in conjunction with vegetation has been shown to reduce the bioavailability of lead in these soils (Brown et al., 2003; Farfel et al., 2005). We found that addition of biosolids resulted in a decrease in soil lead levels to normal background as well as decreasing levels of copper, zinc, iron, and aluminum. In addition, the increased turf cover 
in the biosolids-amended soil serves to trap and filter heavy metals deposited by vehicles.

Soil amendment had a far greater effect on turfgrass survival in this study than did either turfgrass species or cultivar. However, some differences are worth noting. Kentucky bluegrass and red fescue appear to offer the best combination of good persistence and slow vertical growth. Idaho bentgrass is a possibility for drier sites and alkaligrass for sites where it can be allowed to reseed. Tall fescue maintains good cover but has excessive vertical growth, and it is beginning to appear on invasive species lists in some states (Center for Invasive Species and Ecosystem Health, 2010). Perennial ryegrass showed relatively poor persistence even in the biosolids plots and should not be considered a permanent turfgrass for roadsides in New England. Tufted hairgrass also does not appear to be adapted. Kentucky bluegrass, red fescue, and tall fescue are known to persist on roadsides in Rhode Island (Brown and Sawyer, 2011), whereas perennial ryegrass, alkaligrass, and tufted hairgrass do not. Idaho bentgrass is not found outside of cultivation in New England but the related Rhode Island bentgrass (Agrostis capillaris) is widespread on roadsides. There were differences among cultivars in establishment and vertical growth, but not in persistence, so specifying only to the species level should be acceptable. However, more research is needed on kentucky bluegrass because there are known to be large differences between cultivars of this apomictic grass and only the cultivar Diva was included in this study.

\section{Literature Cited}

Alloway, B.J. and A.P. Jackson. 1991. The behaviour of heavy metals in sewage sludge-amended soils. Sci. Total Environ. 100:151-176.

Biesboer, D.D., S. Neid, and B. Darveaux. 1998. Salt tolerance in short-statured native grasses. University of Minnesota, St. Paul and Minnesota DOT, St. Paul, MN.

Block, D. 2000. Controlling erosion from highway projects. Biocycle 41:59.

Bowman, D., G. Cramer and D. Devitt. 2006. Effect of salinity and nitrogen status on nitrogen uptake by tall fescue turf. J. Plant Nutr. 29: 1481-1490.

Brady, N.C. and R.R. Weil. 2008. The nature and properties of soils. 14th Ed. Pearson-Prentice Hall, Columbus, OH. p. 342-343.

Brede, D. 2000. Turfgrass maintenance reduction handbook: Sports, lawns, and golf Ann Arbor Press, Chelsea, MI. p. 321.

Brown, R.N. 2008. Salt tolerance of native grasses with potential for use on roadsides in New England, p. 70-81. In: Stringer, W.C., et al. (eds.). Managing an ecosystem on the edge. Clemson University, Columbia, SC.

Brown, R.N. 2010. Salt tolerance of some potential low-input turfgrass species. ASA, CSSA, and SSSA 2010 International Annual Meetings, 31 Oct. to 4 Nov., Long Beach, CA. 6 Sept. 2011. <http://a-c-s.confex.com/crops/2010am/ webprogram/Paper59309.html >. [abstr.].

Brown, R.N. and C.D. Sawyer. 2011. Plant species diversity of highway roadsides in southern New England. Northeast Naturalist (in press).

Brown, S., R.L. Chaney, J.G. Hallfrisch, and Q. Xue. 2003. Effect of biosolids processing on lead bioavailability in an urban soil. J. Environ. Qual. 32:100-108.

Bryson, G.M. and A.V. Barker. 2002. Sodium accumulation in soils and plants along Massachusetts roadsides. Commun. Soil Sci. Plant Anal. 33:67-78.

Center for Invasive Species and Ecosystem Health. 2010. Invasive.org/tall fescue. 29 July 2011. $<\mathrm{http}$ ://www.invasive.org $>$.

Christians, N. 2004. Fundamentals of turfgrass management. 2nd Ed. Wiley, Hoboken, NJ. p. 80.

Cowley, N., D. Thompson, and C. Henry. 1999. Nitrogen mineralization study: Biosolids, manures, composts. In: Henry C., Sullivan D., Rynk R., Dorsey K., Cogger C.1999. Managing nitrogen from biosolids. WDOE Pub. No. 99-508. Univ of Washington Press, Seattle, WA.

Dernoeden, P.H., M.A. Fidanza, and J.M. Krouse. 1998. Low maintenance performance of five Festuca species in monostands and mixtures. Crop Sci. 38:434-439.

Diesburg, K.L., N.E. Christians, R. Moore, B Branham, T.K. Danneberger, Z.J. Reicher, T. Voigt, D.D. Minner, and R. Newman. 1997. Species for low-input sustainable turf in the U.S. Upper Midwest. Agron. J. 89:690-694.

EPA. 1997. Innovative uses of compost. U.S Environmental Protection Agency.

Epstein, E., J.M. Taylor, and R.L. Chancy. 1976 Effects of sewage sludge and sludge compost applied to soil on some soil physical and chemical properties. J. Environ. Qual. 5:422-426.

Farfel, M.R., A.O. Orlova, R.L. Chaney, P.S.J. Lees, C. Rohde, and P.J. Ashley. 2005. Biosolids compost amendment for reducing soil lead hazards: A pilot study of Orgro ${ }^{\circledR}$ amendment and grass seeding in urban yards. Sci. Total Environ. 340:81-95.

FHWA. 2003. The nature of roadsides and the tools to work with it. US DOT Federal Highway Administration, Washington, DC

Forman, R.T.T., D. Sperling, J.A. Bissonette, A.P. Clevenger, C.D. Cutshall, V.H. Dale, L. Fahrig, R. France, C.R. Goldman, K. Heanue, J.A. Jones, F.J. Swanson, T. Turrentine, and T.C. Winter. 2003. Road ecology: Science and solutions. Island Press, Washington, DC.

Geremia Associates. 2010. Industrial pretreatment program. Annual Report (1 July 2009 to 30 June 2010). West Warwick Regional Wastewater Facility, Providence, RI.

Grebus, M., M. Watson, and H. Hoitink. 1994. Biological, chemical and physical properties of composted yard trimmings as indicators of maturity and plant disease suppression. Compost Sci. Util. 2:57-71.

Haney, R., W. Brinton, and E. Evans. 2008. Estimating soil carbon, nitrogen, and phosphorus mineralization from short-term carbon dioxide respiration. Commun. Soil Sci. Plant Anal. 39:2706-2720.

Hargreaves, J.C., M.S. Adl, and P.R. Warman. 2008. A review of the use of composted municipal solid waste in agriculture. Agric. Ecosyst. Environ. 123:1-14.

Harrell, M.S. 2002. Utilization of composted materials along Florida roadways. University of Florida, Gainesville, FL.

Hutchinson, F.E. and B.E. Olson. 1967. The relationship of road salt applications to sodium and chloride ion levels in the soil bordering major highways. Highw. Res. Rec. 193:1-7.

Imperato, M., P. Adamo, D. Naimo, M. Arienzo, D. Stanzione, and P. Violante. 2003. Spatial distribution of heavy metals in urban soils of Naples City, Italy. Environ. Pollut. 124:247-256.

Joshi, S.R., R. Kumar, P. Saikia, R.K. Bhagobaty, and S. Thokhom. 2010. Impact of roadside pollution on microbial activities in sub-tropical forest soil of north east India. Research Journal of Environmental Sciences 4:280-287.

Krishnan, S. 2010. Physiology and genomics of salt tolerance in Lolium and Festuca. Environmental Science, University of Rhode Island, Kingston, RI.

Marcum, K. 2009. Relative salinity tolerance of turfgrass species and cultivars, p. 389-406. In: Pessarakli, M. (ed.). Handbook of turfgrass management and physiology. CRC Press, Taylor and Francis Group, Boca Raton, FL.

McCoy, J.L., L.J. Sikora, and R.R. Weil. 1986. Plant availability of phosphorus in sewage sludge compost. J. Environ. Qual. 15:403-409.

McKernan, D., J. Ross, and D. Tompkins. 2001. Evaluation of grasses grown under low maintenance conditions. Intl. Turfgrass Soc. Res. J. 9:25-32.

Mintenko, A.S., S.R. Smith, and D.J. Cattani. 2002. Turfgrass evaluation of native grasses for the northern Great Plains region. Crop Sci. 42: 2018-2024.

Muskett, C.J. and M.P. Jones. 1981. Soil respiratory activity in relation to motor vehicle pollution. Water Air Soil Pollut. 15:329-341.

NHI. 2009. Urban drainage design manual. Hydraulic Engineering Circular. Federal Highway Administration, Washington, DC.

OSCS. 2011. Oregon seed certification service handbook. Oregon State University, Corvallis, OR.

Prior, G.A. and P.M. Berthouex. 1967. A study of salt pollution of soil by highway salting. Highw. Res. Rec. 193:8-21.

Richard, T., R. Persyn, and T. Glanville. 2002. Cover crop production and weed control on highway right-of-ways using composted organics. American Society of Agricultural Engineers, St. Joseph, MI. ASAE Paper No. 022051.

RIDOT. 2004. Standard specifications for road and bridge construction. Rhode Island Department of Transportation, Providence, RI.

Ruxton, G.D. and N. Colgrave. 2003. Experimental design for the life sciences. Oxford University Press, Oxford, UK. p. 78-79.

Saxton, K.E. 2009. Soil water characteristics. 28 Feb. 2011.<http://hydrolab.arsusda.gov/soilwater/ Index.htm>

Spencer, J.H., N.E. Scott, G.R. Portm, and A.W. Davison. 1988. Effects of roadside conditions on plants and insects. I: Atmospheric conditions. J. Appl. Ecol. 25:699-707.

Steel, R.G.D. and J.H. Torrie. 1980. Principles and procedures of statistics. 2nd Ed. McGraw-Hill, New York, NY.

Truscott, A.M., S.C.F. Palmer, G.M. McGowan, J.N. Cape, and S. Smart. 2005. Vegetation composition of roadside verges in Scotland: The effects of nitrogen deposition, disturbance and management. Environ. Pollut. 136:109-118.

Turer, D., J. Maynard, and J. Sansalone. 2001. Heavy metal contamination in soils of urban highways: Comparison between runoff and soil concentrations at Cincinnati, Ohio. Water Air Soil Pollut. 132:293.

Wakefield, R., C. Sawyer and B. Lowe. 1981. Management and renovation of roadside turfgrass. RI Agr. Exp. Sta. Bull. 431.

Wakefield, R.C., R.S. Bell, J.A. Jagschitz, A.J. Clapham, A.T. Dore, A.P. Nielsen and B.C. Laskey. 1974. Establishment of roadside vegetation in Rhode Island. RI Agr. Exp. Sta. Bull. 416.

Walter, I. and G. Cuevas. 1999. Chemical fractionation of heavy metals in a soil amended with repeated sewage sludge application. Sci. Total Environ. 226:113-119.

Yang, Y., Z. He, P.J. Stoffella, D.A. Graetz, X. Yang, and D.J. Banks. 2008. Leaching behavior of heavy metals in biosolids amended sandy soils. Compost Sci. Util. 16:144-151. 